Int. J. Plant Sci. 169(3):455-471. 2008.

(c) 2008 by The University of Chicago. All rights reserved.

1058-5893/2008/16903-0011\$15.00 DOI: $10.1086 / 526463$

\title{
A SEARCH FOR PHYLOGENETICALLY INFORMATIVE POLLEN CHARACTERS IN THE SUBTRIBE SALVIINAE (MENTHEAE: LAMIACEAE)
}

\author{
Hye-Kyoung Moon, ${ }^{1, *}$ Stefan Vinckier, † Jay B. Walker, $\neq$ Erik Smets, ${ }^{*} \S$ and Suzy Huysmans* \\ *Laboratory of Plant Systematics, Institute of Botany and Microbiology, Katholieke Universiteit Leuven, Kasteelpark Arenberg 31, \\ P.O. Box 2437, BE-3001 Leuven, Belgium; †Center for Transgene Technology and Gene Therapy, Flanders Institute for \\ Biotechnology (VIB-3), Katholieke Universiteit Leuven, Herestraat 49, BE-3000 Leuven, Belgium; ‡Department of \\ Botany, University of Wisconsin, Madison, Wisconsin 53706, U.S.A.; and §National Herbarium of the \\ Netherlands, Leiden University Branch, P.O. Box 9514, NL-2300 RA Leiden, The Netherlands
}

\begin{abstract}
The pollen morphology and ultrastructure of the subtribe Salviinae were investigated with light, scanning electron, and transmission electron microscopy. In addition, cladistic analyses of the obtained morphological data, supplemented with $r b c L$ data from GenBank, were conducted in order to assess the phylogenetic signal of palynological characters. Salviinae pollen is small to large, oblate to prolate in shape, with a circular to slightly elliptic amb, and mostly hexacolpate. Perovskia abrotanoides appears to be distylous and shows a significant pollen dimorphism between pin and thrum flowers. The sexine ornamentation of the genera Lepechinia and Chaunostoma is perforate, while the ornamentation of other genera is bireticulate. Perovskia expresses a unique type of sexine ornamentation. The sexine ornamentation variation in Salvia has systematic importance but only partly corresponds with current phylogenetic hypotheses. Unbranched columellae and a continuous, granular endexine are hypothesized to be a symplesiomorphic condition in the tribe Mentheae. Our combined phylogenetic analyses show that the addition of palynological characters contributes to improved resolution and also increases bootstrap support values in comparison with molecular phylogenetic analyses.
\end{abstract}

Keywords: distyly, palynology, Perovskia, phylogeny, pollen dimorphism, Salviinae.

\section{Introduction}

Lamiaceae is a cosmopolitan family with more than 236 genera and ca. 7000 species (Thorne 1992). Mentheae is the largest and economically most important tribe of the subfamily Nepetoideae. The subfamily is characterized by hexacolpate pollen, exalbuminous seeds, and an investing embryo type (Cantino 1992). Mentheae includes many common culinary herbs such as balm (Melissa), bee balm (Monarda), catnip (Nepeta), mint (Mentha), oregano (Origanum), rosemary (Rosmarinus), sage (Salvia), savory (Satureja), and thyme (Thymus). Mentheae can be divided into three subtribes, Salviinae, Menthinae, and Nepetinae, and accommodates ca. 65 genera (Harley et al. 2004).

This study focuses on the morphological variation of pollen within the subtribe Salviinae, with special attention on the genus Salvia, and it plays an integral part in a detailed overview of pollen morphology in the tribe Mentheae. Although general palynological data proved to be systematically useful within the family at a high taxonomic level (Erdtman 1945), a thorough palynological study of the tribe Mentheae is lacking to date (Wagstaff 1992).

Subtribe Salviinae consists of eight genera, and these genera have been classified differently according to various authors (table 1; Harley et al. 2004). In spite of the complicated taxo-

${ }^{1}$ Author for correspondence; e-mail: hyekyoung.moon@bio .kuleuven.be.

Manuscript received March 2007; revised manuscript received August 2007. nomic history, Salviinae turns out to be a well-supported monophyletic subtribe within the tribe Mentheae, on the basis of recent molecular data (Walker and Sytsma 2007). However, the relationships among the genera of Mentheae are poorly understood (Harley et al. 2004). Salvia is by far the largest genus of the family and represents a cosmopolitan assemblage of ca. 1000 species, displaying a remarkable morphological variation. Bentham (1876) separated the genus Salvia into 12 sections based on stamen variation, which remains until now the most widely accepted treatment (Briquet 1897; Stibal 1934, 1935; Epling 1938, 1939; Pobedimova 1954; Hruby 1962). The evolution of the stamen connective and unique lever mechanism has occurred parallel in the Old World and the New World (Claßen-Bockhoff et al. 2004; Walker and Sytsma 2007). The demonstration of the nonmonophyletic origin of Salvia based on molecular data (Walker et al. 2004; Walker and Sytsma 2007) has led to the reinvestigation of morphological characters in Salvia and closely related genera in the subtribe Salviinae.

Previous pollen morphological studies in Salvia and related taxa have mainly been based on light microscopic (LM) observations (Emboden 1964; Henderson et al. 1968; Varghese and Verma 1968; Vij and Kashyap 1975). Afzal-Rafii (1983) observed ca. 40 species of Salvia using LM and scanning electron microscopy (SEM). However, all of the species he studied were restricted to the Old World. Trudel and Morton (1992) and Wagstaff (1992) investigated the surface ornamentation of pollen of a few Salvia species and various other selected genera of the family by means of SEM. Transmission electron 


\section{Table 1}

Genera of Subtribe Salviinae sensu Harley et al. (2004) and Their Previous Taxonomic Positions

\begin{tabular}{llll}
\hline Harley et al. 2004 & Bentham 1876 & Briquet 1897 & Wunderlich 1967 \\
\hline Chaunostoma Donn. Sm. (1/1) & NI & Incertae sedis & NI \\
Dorystaechas Boiss. \& Heldr. (1/1) & Monardeae & Meriandreae & Meriandreae \\
Lepechinia Willd. (2/40) & Satureineae & Lepechinieae & Lepechinieae \\
Meriandra Benth. (1/2) & Monardeae & Meriandreae & Meriandreae \\
Perovskia Kar. $(2 / 7)$ & Monardeae & Meriandreae & Meriandreae \\
Rosmarinus L. (1/3) & Monardeae & Ajugoideae & Ajugoideae \\
Salvia L. (32/900) & Monardeae & Salvieae & Salvieae \\
Zhumeria Rech. f. \& Wendelbo (0/1) & NI & NI & NI \\
\hline
\end{tabular}

Note. $\mathrm{NI}=$ not indicated. The first number in parentheses indicates the number of species studied in this article, and the second number represents the total number of species.

microscopic (TEM) observations are not available for the subtribe Salviinae.

The presence/absence of orbicules and their morphology can provide additional palynological characters that might have a phylogenetic significance (e.g., Raj and El-Ghazaly 1987; Huysmans et al. 1998; Vinckier and Smets 2002). Orbicules are small sporopollenin particles that can be produced in species with a secretory tapetum (Huysmans et al. 1998, 2000). Until now, the presence of orbicules has not been investigated systematically in Lamiaceae (Huysmans et al. 1998, 2000). Orbicules have been recorded only in Chloanthaceae (Raj and El-Ghazaly 1987; tribe Chloantheae of Lamiaceae sensu Harley et al. 2004). Orbicules may also occur in Lavandula dentate L., which possesses a secretory tapetum (Suarez-Cervera and Seoane-Camba 1986), although this has yet to be confirmed.

This study aims to document and illustrate the pollen morphology as well as the ultrastructure of the pollen wall and to trace the occurrence of orbicules in Salviinae sensu Harley et al. (2004) by using LM, SEM, and TEM. In order to check the phylogenetic significance of the obtained palynological data, we analyzed pollen characters cladistically in combination with $r b c L$ data from GenBank. The results are discussed with a focus on the infrageneric relationships within Salvia.

\section{Material and Methods}

\section{Material}

This study is based on herbarium material of 40 species (54 specimens) from seven genera of the subtribe Salviinae, collected from following herbaria: BR, GH, LV, and MO (acronyms follow Holmgren et al. 1990; for a complete list of specimens, see app. A). These species of Salvia were carefully chosen based on previously recognized infrageneric groups and geographic ranges (Walker et al. 2004).

\section{Pollen Morphology}

Pollen grains of all species investigated were acetolyzed according to Reitsma's (1969) method and described on the basis of LM and SEM observations. The glycerin jelly slides (LM) were observed using a Leitz Dialux 20 microscope and were photographed with an Olympus DP 50 digital camera. In order to study the exine stratification and inner exine ornamentation on fractured pollen, we placed acetolyzed grains in an ultrasonic bath for up to $20 \mathrm{~min}$. Acetolyzed pollen grains were suspended in ethanol, air dried on a stub, and coated with gold (SPI sputter-coater) before observation with a JEOL JSM-6360 scanning electron microscope at 20-25 kV. Measurements of the length of the polar axis $(P)$, equatorial diameter $(E)$, colpus length $(C)$, and exine thickness were made with LM on 15-20 fully developed grains of each specimen.

\section{Orbicule Morphology}

For morphological observations of orbicules, dried flowers or buds were rehydrated for 1-2 h (Agepon wetting agent, $1: 200)$. Anthers were separated from the flowers, and the tips were removed with a razor blade to facilitate rehydration. After dissection, the anthers remained for one more hour in the wetting agent. Following dehydration in a graded acetone series, the material was critical-point dried (CPD 030, Balzers). The dried anthers were mounted on stubs with double-adhesive tape. The locules were opened, and the pollen grains were carefully removed with a cactus needle. The removed pollen grains were collected on the same stub in order to observe criticalpoint-dried grains. The size measurements of acetolyzed and critical-point-dried pollen grains on SEM photographs were compared using Carnoy 2.0 (Schols et al. 2002).

\section{Ultrastructure}

For TEM, the anthers were rehydrated in $0.05 \mathrm{M}$ sodium cacodylate buffer ( $\mathrm{pH} 7.3$ ) before fixation. The material was fixed in $2.5 \%$ glutaraldehyde and buffered with $0.05 \mathrm{M}$ sodium cacodylate $\left(\mathrm{pH} 7.3\right.$ ), followed by postfixation with $2 \% \mathrm{OsO}_{4}$. Before embedding in LR-White Resin (Polysciences, Warrington, PA), the material was dehydrated in a graded ethanol series. Semithin sections $( \pm 1 \mu \mathrm{m})$ were cut with a microtome (Reichert Jung Ultracut E), stained with $0.1 \%$ thionin- $0.1 \%$ methylene blue, and observed with a Leitz Dialux 20 microscope. The ultrathin sections on copper grids were stained with uranyl acetate and lead citrate in an ultrastainer (LKB 2168) and observed with a Zeiss EM 900 transmission electron microscope at $50 \mathrm{kV}$. Size differences of distylous species were statistically analyzed with a $t$-test using the SAS software package (release 8.00; SAS Institute, Cary, NC). Pollen terminology follows the online edition of the Glossary of Pollen and Spore Terminology (Punt et al. 1994; http://www.bio.uu.nl/ palaeo/ glossary/glos-int.htm). 


\section{Selecting Characters and Coding Data}

A total of 13 morphological characters were assembled and are presented in appendix B. The matrix is presented in appendix C. Continuous characters such as pollen size (characters 1-6) were coded using Thiele's (1993) gap weighting method, as implemented by MorphoCode (Schols et al. 2004a). MorphoCode exports newly coded data to a NEXUS file (Maddison et al. 1997). The gap weighting method considers distribution of the mean values for a certain character and converts them to ordered multistate characters. The distance between the means is represented by the distance between the ordered character states in the matrix. The number of possible character states for the continuous characters was set to 10 . Therefore, the continuous characters were given a weight of 0.1 and ordered, while all the other discrete characters have a weight of 1 and were unordered for the equivalent of all characters.

\section{Cladistic Analysis}

We selected 32 taxa for which both morphological and $r b c L$ molecular data (1246 characters from GenBank; Walker et al. 2004) were available. Parsimony analyses were performed using PAUP*, version 4.0b10 (Swofford 2002). The morphological and molecular data sets were analyzed separately and combined.

We analyzed each matrix using a heuristic search with 1000 random input orders and tree-bisection-reconnection (TBR) branch swapping and holding five trees per step. Bootstrap values were calculated with 1000 replicates, employing a heuristic search with 100 replicates and TBR swapping and holding five trees per step (Felsenstein 1985). The strict consensus trees were compared to discern differences between the analysis of the $r b c L$ data and the combined analysis.

MacClade, version 4.0 (Maddison and Maddison 2000), was used to optimize morphological characters on the most parsimonious tree topology from molecular data alone. This topology was preferred over one generated from the combined data set, which already included palynological characters.

\section{Results}

\section{Palynological Characters of Salviinae}

Pollen of Salviinae shows variation in size, shape, number of apertures, and sexine ornamentation. The main pollen characters are summarized in table 2. Representative pollen grains are illustrated in figures 1-5.

\section{Palynological Characters of Salviinae: Size}

The pollen grains are shed as monads, and their size ranges from small to large: $P=20.5-69.4 \mu \mathrm{m}$ and $E=18.4-72.9 \mu \mathrm{m}$ (table 2; fig. 1A-1F). The largest pollen grain is observed in Salvia eremostachya $(P=69.4 \mu \mathrm{m}, E=72.9 \mu \mathrm{m}$; fig. $1 A)$, and the smallest grain is present in $S$. polystachya $(P=20.5 \mu \mathrm{m}$, $E=18.4 \mu \mathrm{m}$; fig. 1A). Perovskia abrotanoides is distylous and shows significant pollen dimorphism (table 2; fig. $2 \mathrm{G}, 2 \mathrm{H}$ ). Pollen grains are significantly larger in thrum than in pin flowers ( $E: p<0.0001 ; P: p<0.001)$. It is important to note that the size of critical-point-dried pollen grains is $8 \%-40 \%$ smaller than acetolyzed pollen grains (both observed with SEM under the same conditions).

\section{Palynological Characters of Salviinae: Shape}

The polar outlines are slightly elliptic to circular; in equatorial view, the grains are oblate to prolate $(P / E=0.73-1.43$; fig. 1). The oblate-spheroidal to subprolate shape occurs in the majority of the taxa studied. The length of the polar axis and the equatorial diameter of pollen grains have a positive correlation $\left(R^{2}=0.866\right)$. Only pollen grains of $S$. splendens have an oblate shape. However, shape classes can vary considerably within taxa (table 2; fig. $1 B-1 F$ ).

\section{Palynological Characters of Salviinae: Apertures}

All species examined are predominantly hexacolpate, but seven species possess tetra-, penta-, or octocolpate pollen grains (fig. $1 G-1 R$ ). Dorystaechas hastata and S. splendens have ca. $5 \%$ tetracolpate pollen grains. Salvia eremostachya, S. leucantha, and S. palaestina have less than $1 \%$ tetracolpate pollen grains. In $S$. eremostachya and $S$. splendens, we observed a few pentacolpate pollen grains, and in $S$. barrelieri, $S$. palaestina, and $S$. uliginosa, one octocolpate pollen grain was observed. The colpi are distributed symmetrically and sometimes are secondarily bilateral at the equatorial plane. Sometimes the mesocolpia differ in size on one grain. If the amb is circular, three wider mesocolpia might alternate with three narrower ones (fig. $1 \mathrm{~K}$ ). While the amb is elliptic, there are four narrower mesocolpia and two wider ones each at opposite sides (fig. 1N). The range of colpi length in all taxa studied is 11.4$54.1 \mu \mathrm{m}$. Colpus length is strongly correlated with the length of the polar axis $\left(R^{2}=0.9565\right)$. The polar apocolpium index is between 0.06 and 0.41 (table 2). Colpus ends are acute, and colpus membranes are beset with granules (figs. 1-5).

\section{Palynological Characters of Salviinae: Sexine Ornamentation}

Three distinct sexine ornamentation types are described, and in type III, four subtypes have been recognized on the basis of the ratio of the muri thickness and the shape and number of secondary lumen.

1. Pollen with bireticulum . ........... 2

Pollen without bireticulum, finely perforate. . . . . . Type I

2. Muri of primary reticulum thicker than secondary muri; lumen of primary reticulum contains fewer than five units of secondary lumen ............... Type II

Muri of primary reticulum thicker or similar than secondary muri; lumen of primary reticulum contains more than five units of secondary lumen. . . . . . . . . . Type III

\section{Sexine Ornamentation: Type I: Chaunostoma and Lepechinia (Fig. 2A-2E)}

The sexine ornamentation is perforate, although some perforations are elongated and subdivided into two or three smaller units by muri at a slightly lower level. The distance between the edges of adjacent perforations is greater than the diameter of perforations. Perforations at the poles are slightly smaller than those at the equator. Species observed: Chaunostoma mecistandrum, Lepechinia calycina, and L. caulescens. 


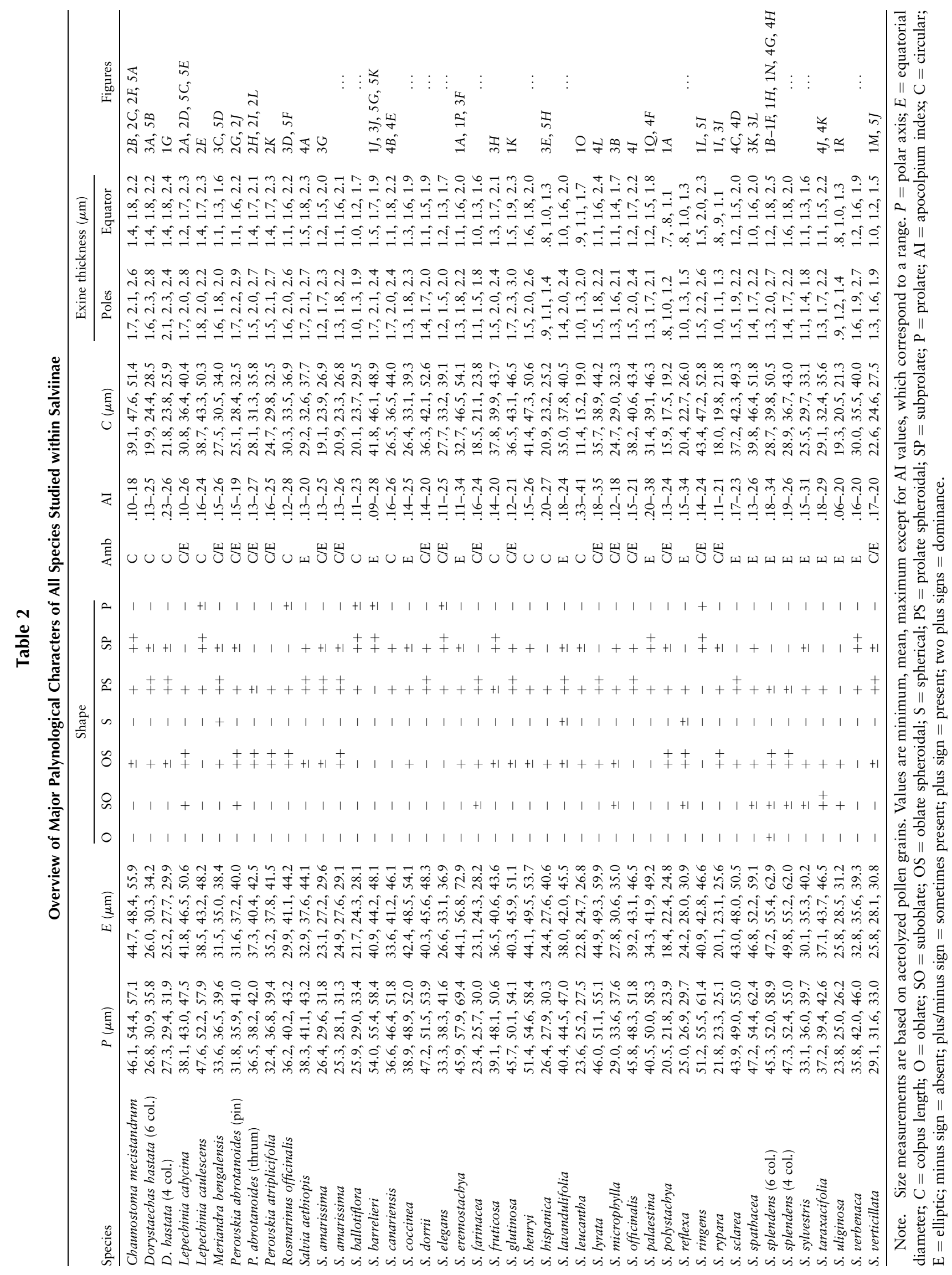




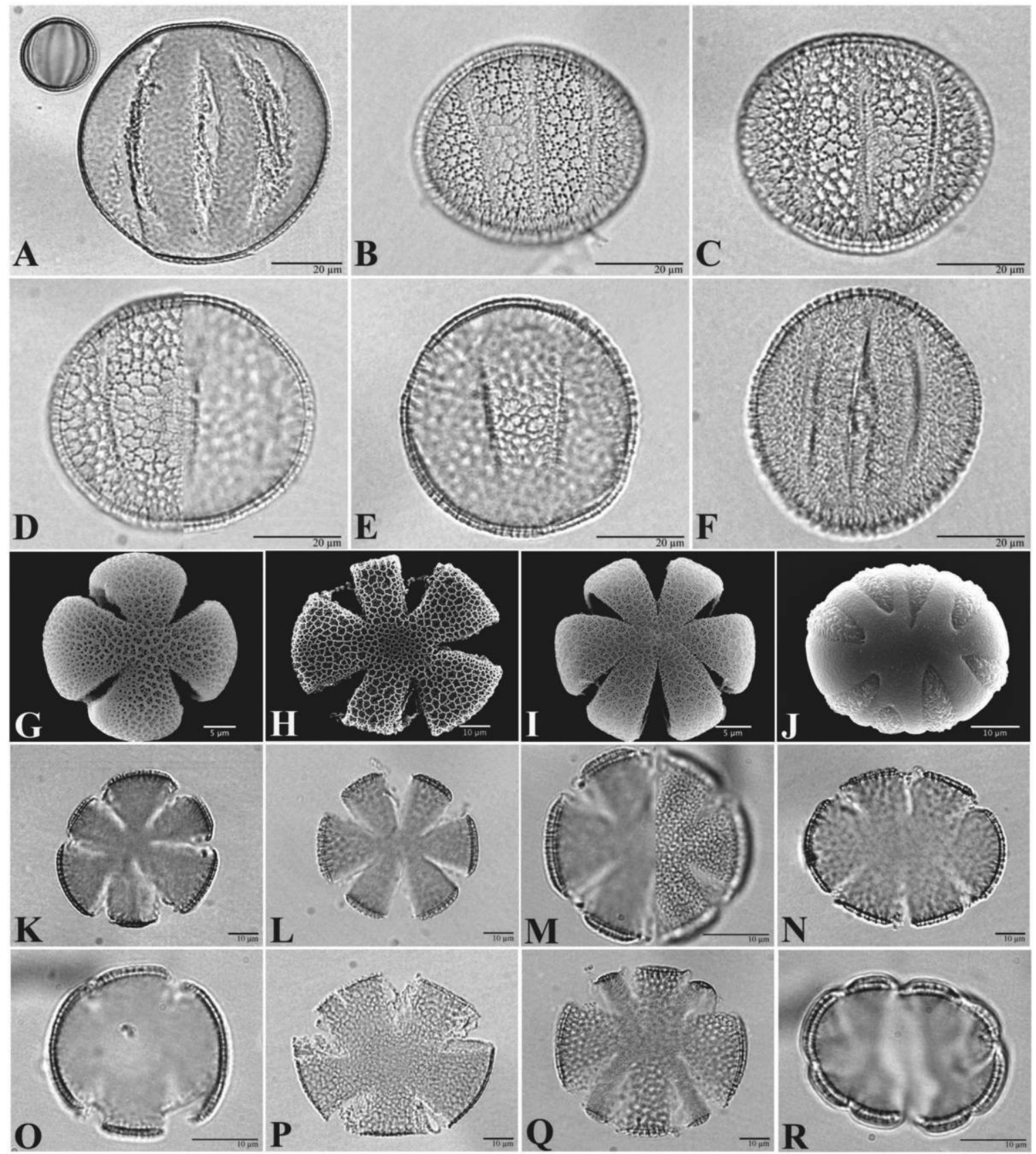

Fig. 1 LM and SEM micrographs of Salviinae pollen grains. A, Size variation of Salviinae; upper left: Salvia polystachya (smallest species); middle: Salvia eremostachya (largest species). B-F, Shape variations in Salvia splendens. G-J, Polar view showing variations in aperture numbers. $G$, Dorystaechas hastata. H, Salvia splendens. I, Salvia rypara. J, Salvia barrelieri; critical-point-dried pollen grain. K-N, Polar view of hexacolpate pollen with shape variations. K, Salvia glutinosa. L, Salvia ringens. M, Salvia verticillata. N, Salvia splendens. O-R, Polar view showing variations of aperture numbers. O, Salvia leucantha. P, Salvia eremostachya. Q, Salvia palaestina. R, Salvia uliginosa.

Sexine Ornamentation: Type II: Perovskia (Fig. 2G-2L)

The sexine is bireticulate. The primary muri are more than twice as thick as the secondary muri. Primary lumina are continuous, irregular to rounded, and slightly shallow. The secondary reticulum is microreticulate; the number of secondary lumina does not exceed five, on average, for each primary lumen. The perforation size and secondary lumen number decrease toward the poles and apertures. Species observed: Perovskia abrotanoides and P. atriplicifolia.

Sexine Ornamentation: Type III: Dorystaechas, Meriandra, Rosmarinus, and Salvia (Figs. 3, 4)

The sexine is obviously bireticulate. The primary muri are thicker than or of a width similar to that of the secondary muri. 

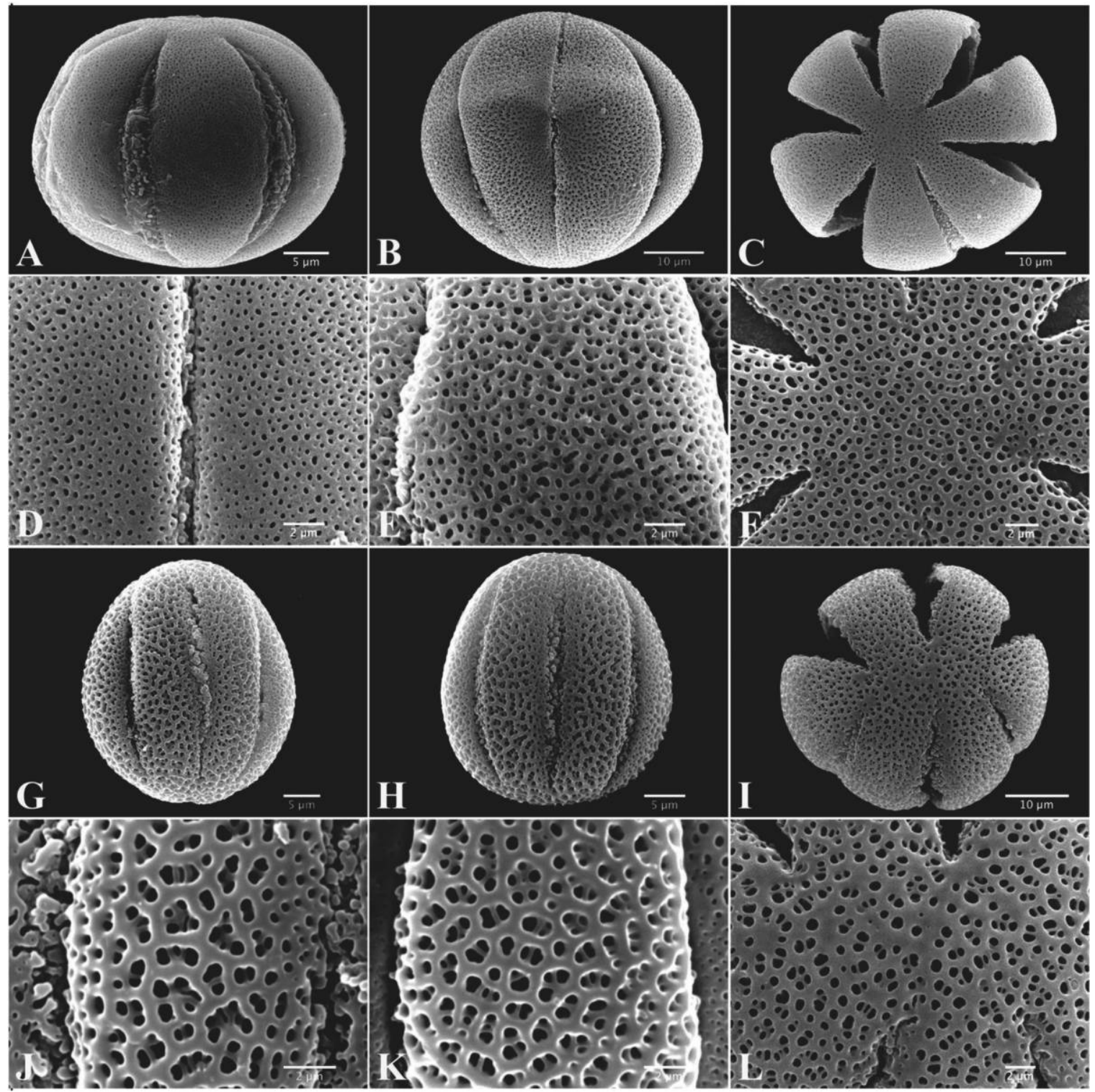

Fig. 2 SEM micrographs of the genera Chaunostoma, Lepechinia, and Perovskia. A-F, Sexine ornamentation type I: perforate. G-L, Sexine ornamentation type II: bireticulate with small units of secondary reticulum. $A, B, G, H$, Equatorial view. $C, I$, Polar view. $D-F, J-L$, Detailed view of sexine ornamentation. A, D, Lepechinia calycina. A, Critical-point-dried pollen grain. B, C, F, Chaunostoma mecistandrum. E, Lepechinia caulescens. G, J, Perovskia abrotanoides, pin type. $H, I, L$, Perovskia abrotanoides, thrum type. K, Perovskia atriplicifolia.

Primary lumina are continuous and vary in shape from irregular ellipses to polygons. The primary lumen consists of more than five units of secondary lumina. We recognized four different subtypes to describe the observed variation in type III.

Subtype IIIa. The primary muri are twice as thick as the secondary muri, with rounded and irregular or sometimes discontinuous primary lumen shape. The number of secondary lumina is five to 10 per primary lumen (fig. $3 A-3 F$ ). Species observed: Dorystaechas hastata, Meriandra bengalensis, Rosmarinus officinalis, Salvia dorrii, S. eremostachya, S. glutinosa, S. hispanica, and S. verticillata.

Subtype IIIb. The primary muri are thicker than the secondary muri; the shape of the primary lumina is rounded and continuous. The secondary lumina are regular; at the mesocolpia, more than 10 secondary lumina per primary lumen were counted; toward colpi and poles, the size of the primary lumina decreased (fig. 3G-3I). Species observed: S. amarissima, S. ballotiflora, S. barrelieri, S. coccinea, S. elegans, S. farinacea, S. fruticosa, S. henryi, S. lavandulifolia, S. leucantha, S. microphylla, S. polystachya, S. reflexa, S. ringens, S. rypara, S. sylvestris, $S$. uliginosa, and $S$. verbenaca.

Subtype IIIc. Similar to subtype IIIb but the secondary reticulum consists of one or several large lumina in the middle of the primary lumen (fig. $4 A-4 F$ ). The number of secondary lumina exceeds 10 per primary lumen. Species observed: $S$. aethiopis, $S$. canariensis, S. palaestina, and S. sclarea. 


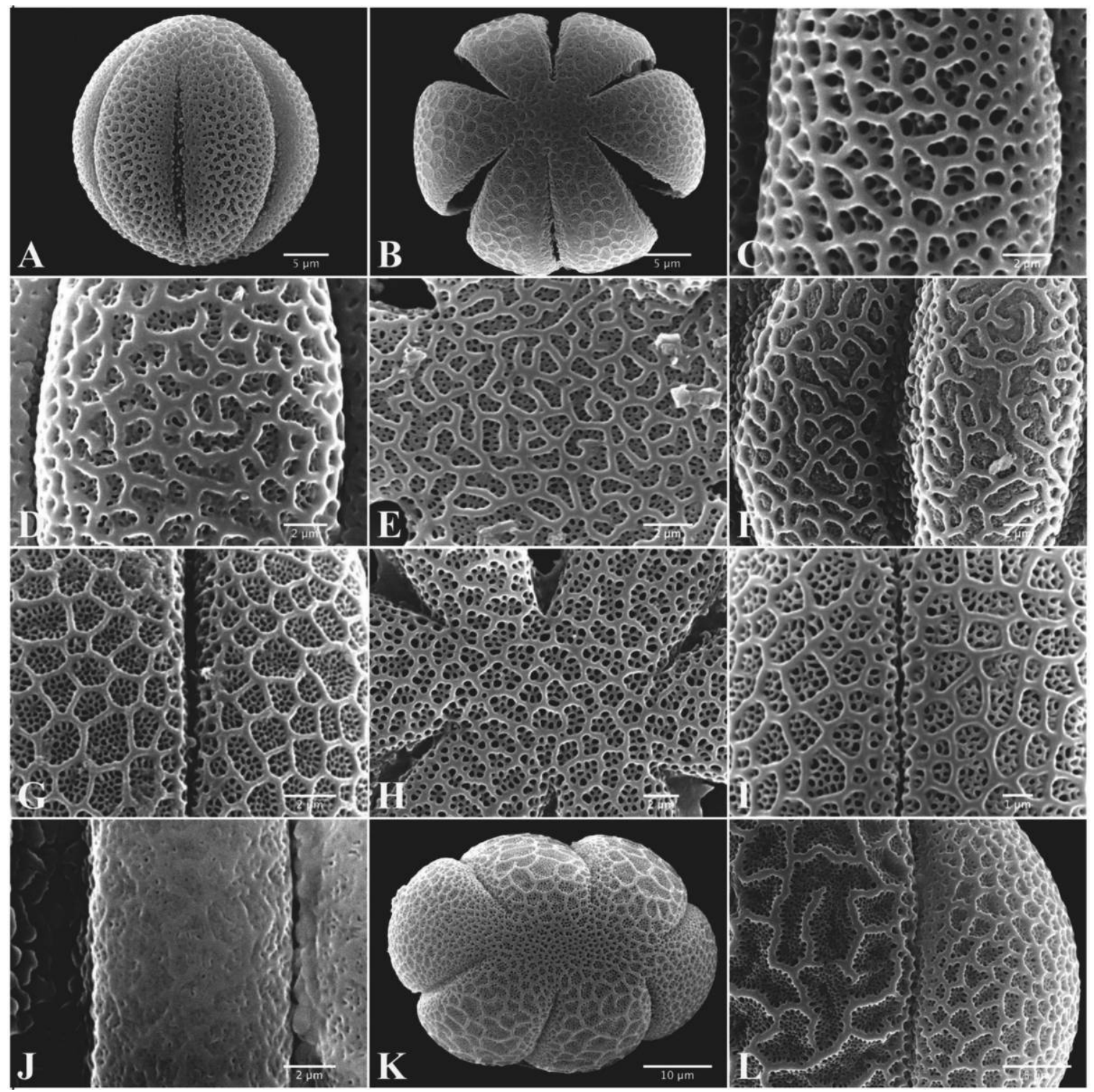

Fig. 3 SEM micrographs of the genera Dorystaechas, Meriandra, Rosmarinus, and Salvia. A, C-F, Sexine ornamentation subtype IIIa: bireticulate with thick primary muri. $B, G-I$, Sexine ornamentation subtype IIIb: bireticulate with coarsely secondary reticulum. $J$, Unclear secondary reticulum in Salvia barrelieri. $K, L$, Detail of the heteromorphic sculpturing pattern of S. spathacea. A, Equatorial view: Dorystaechas hastata. B, Polar view: Salvia microphylla. C, Meriandra bengalensis. D, Rosmarinus officinalis. E, Salvia hispanica. F, Salvia eremostachya. G, Salvia amarissima. H, Salvia fruticosa. I, Salvia rypara.

Subtype IIId. Thickness of primary and secondary muri is rather similar. Lumina of primary reticulum are filled with large lumina of the secondary reticulum (fig. 4I-4L). Species observed: S. lyrata, S. officinalis, and S. taraxacifolia.

Salvia barrelieri and S. eremostachya show an unclear secondary reticulum, although pollen grains were taken from fully mature flowers and several specimens of $S$. barrelieri were studied (fig. 3F, 3J; see app. A). However, we can classify S. barrelieri into subtype IIIb and S. eremostachya into subtype IIIa, on the basis of primary muri thickness and lumen shape. Salvia spathacea has a remarkable heteromorphic sculpturing pattern with discontinuous primary muri. On the two lateral mesocolpia at the edges of the grains, primary lumina size was smaller than that on the four middle mesocolpia. At the poles, the size of the primary lumina was comparable to that at the middle of the mesocolpia (fig. $3 K, 3 L$ ). Salvia splendens has a secondary reticulum with a large lumen in the middle and thin primary muri (fig. $4 G, 4 H$ ).

\section{Palynological Characters of Salviinae: Pollen Wall Stratification and Ultrastructure}

On average, the exine is slightly thicker at the poles than at the equator, but there are no significant differences (table 2). Basically, all taxa studied show the same exine stratification. The tectum is somewhat thicker than the foot layer (fig. 

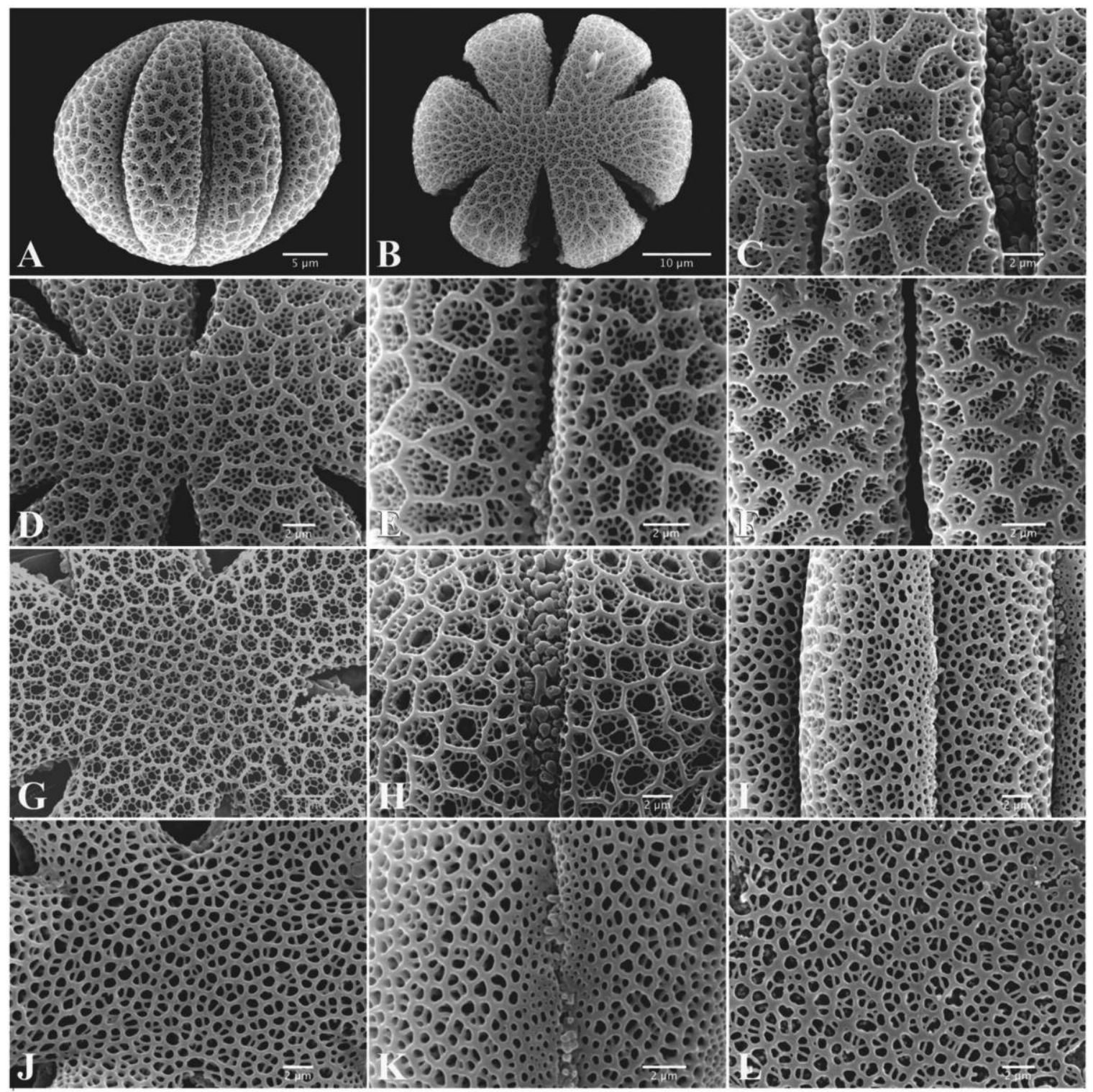

Fig. 4 SEM micrographs of Salvia. A-F, Sexine ornamentation subtype IIIc: bireticulate with large secondary lumina in the middle of the primary lumen. $G, H$, Thin primary muri with a large perforation in the middle of the primary lumen in Salvia splendens. I-L, Sexine ornamentation subtype IIId: bireticulate with thin primary muri and big secondary lumina. A, Equatorial view: Salvia aethiopis. B, Polar view: Salvia canariensis. C, D, Salvia sclarea. E, Salvia canariensis. F, Salvia palaestina. I, Salvia officinalis. J, K, Salvia taraxacifolia. L, Salvia lyrata.

$5 A-5 H)$. The primary reticulum is always simplicolumellate. Columellae are densely spaced and unbranched, their length being nearly twice the thickness of the tectum. The foot layer is continuous, and the endexine is irregular and continuous and has a granular appearance (fig. $5 A-5 H$ ). The intine is nearly as thick as the tectum, and two strata can be observed on the basis of differences in electron density (fig. $5 E-5 H$ ). Pollenkitt is accumulated in the infratectum (fig. $5 E-5 G$ ).

\section{Palynological Characters of Salviinae: Orbicules}

The possible presence of orbicules in the anthers was checked in 13 species belonging to seven genera (app. A). Orbicules were absent in all the species investigated. The inner locule wall displays a characteristic annular shape because of the underlying prominent endothecium thickenings. The tapetal membrane is completely smooth, without any sporopollenin deposition (fig. 5I-5K).

\section{Phylogenetic Impact of Palynological Characters}

We analyzed 62 parsimony-informative characters (10 morphological characters and 52 molecular characters) from a total of 1257 characters in 32 Salviinae taxa. The strict consensus tree based only on palynological data (apps. B, C) is completely unresolved (fig. 6; consistency index $[\mathrm{CI}]=0.37$, retention in$\operatorname{dex}[\mathrm{RI}]=0.71$, rescaled consistency index $[\mathrm{RC}]=0.26)$. The parsimony analysis of the $r b c L$ data resulted in 474 equally 

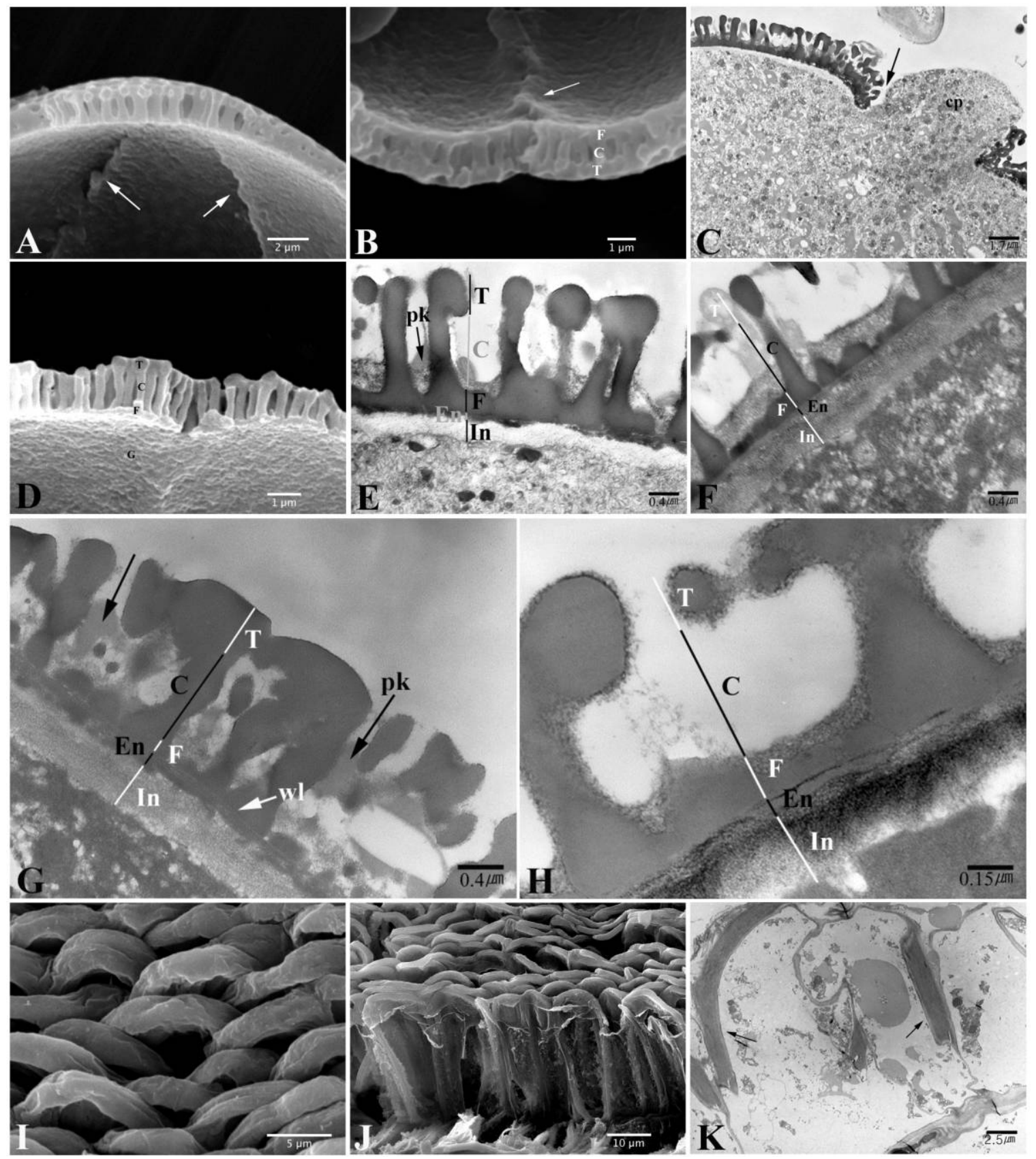

Fig. 5 SEM and TEM micrographs of Salviinae. $A, B, D$, Exine stratification and undifferentiated endexine ornamentation with a densely granular texture $(G)$; white arrows indicate the aperture slit. $C$, Papilla protruding through an aperture, consisting of cytoplasm $(c p)$. The black arrow indicates the border between mesocolpium region and the aperture: Lepechinia calycina. E-H, TEM observation of the ultrastructure of the pollen wall showing tectum $(T)$, columellae $(C)$, foot layer $(F)$, endexine $(E n)$, and intine $(I n)$. G, Magnified part of the wall to emphasize the endexine with remains of the white line $(w l$; white arrow) and deposit of pollenkitt ( $p k$; black arrows) in the infratectum. I, Inner locule wall with no traces of orbicules: Salvia ringens. J, Structure of the endothecium thickenings in cross section: Salvia verticillata. K, Detailed TEM observation of endothecium thickenings (black arrows): Salvia barrelieri. A, Chaunostoma mecistandrum. B, Dorystaechas hastata. D, Meriandra bengalensis. E, Lepechinia calycina. F, Rosmarinus officinalis. H, Salvia hispanica.

parsimonious trees $(\mathrm{CI}=0.71, \mathrm{RI}=0.85, \mathrm{RC}=0.60)$. Two most parsimonious trees were found from combined data set, and the strict consensus tree is similar to the $r b c L$ topology (fig. $7 B ; \mathrm{CI}=0.61, \mathrm{RI}=0.78, \mathrm{RC}=0.48$ ), with improved resolution across the entire tree and also higher bootstrap support values in clade III (fig. 7A).
The genus Salvia appears to be polyphyletic, with representatives in two monophyletic clades (I, II) and a paraphyletic group that forms a clade with Dorystaechas (clade III). Perovskia is sister to Salvia clade I and Rosmarinus, although with only moderate bootstrap support (BS; BS $=84$ vs. 79). Clade II is sister to clade I, Perovskia, and Rosmarinus, with moderate 


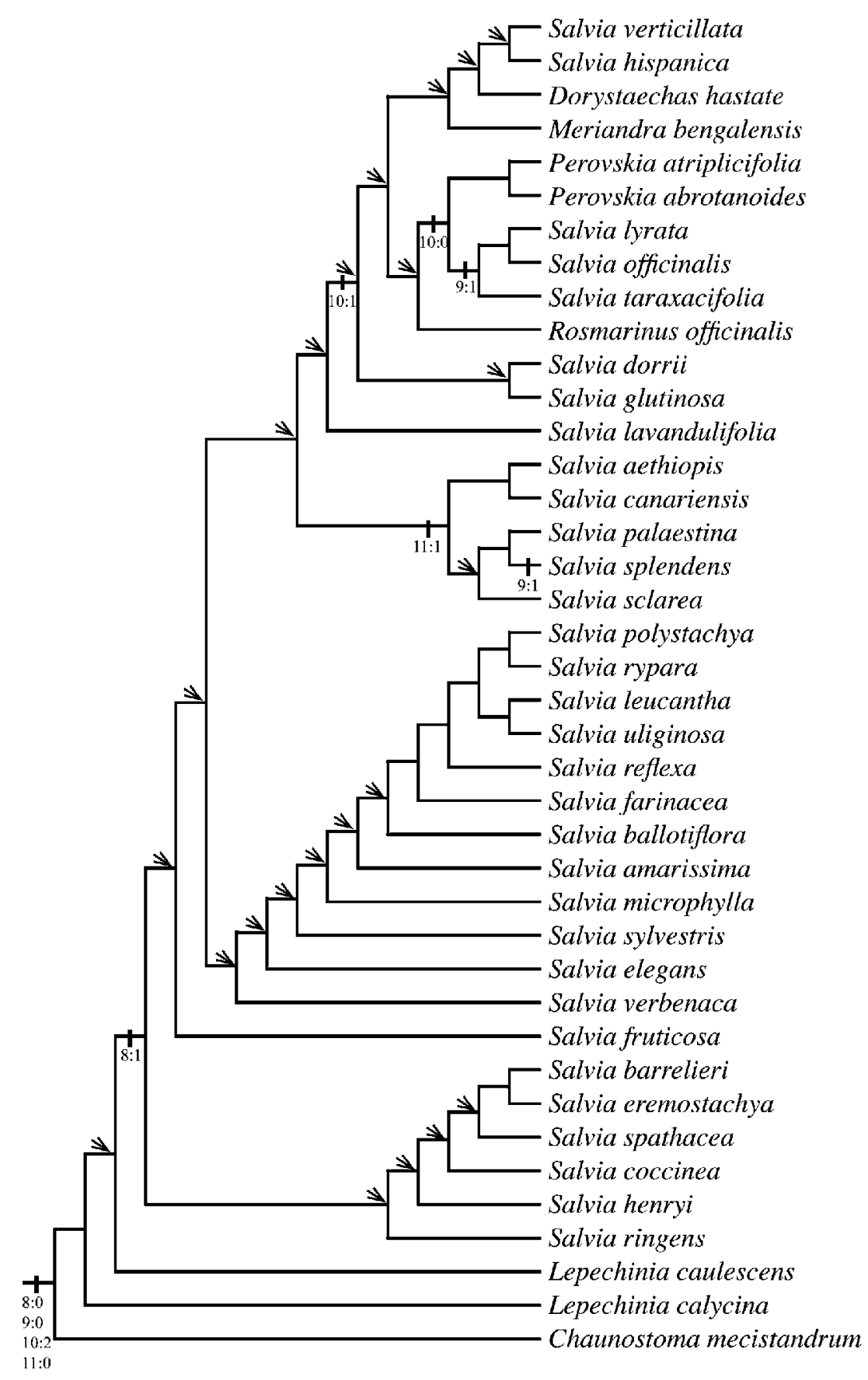

Fig. 6 One of 557 most parsimonious trees resulting from the pollen data analysis showing the distribution of palynological features. Arrows point to branches that are not present in strict consensus tree.

support (BS $=66$ vs. 69). There is low BS for the monophyly of clade II in the combined analysis (BS $=54)$, although it remains unresolved in the analysis of the $r b c L$ data set (fig. $7 B$ ). Clade III combines representatives of Salvia subgenus Calosphace with three species of section Audibertia and forms a moderately supported clade with Dorystaechas (BS $=63$ vs. 60 ). The subgenus Calosphace has better BS in the combined analysis, while it is only moderately supported in the $r b c L$ tree $(B S=89$ vs. 80$)$.

\section{Discussion}

\section{Pollen Morphological Variation of Subtribe Salviinae}

Salviinae species have small to large hexacolpate (sometimes tetra-, penta-, or octocolpate; fig. 1) pollen with an oblate to prolate shape and perforate or bireticulate sexine ornamentation (figs. 2-4). The colpus membranes are beset with granules, and orbicules are lacking (fig. $5 I-5 K$ ). 

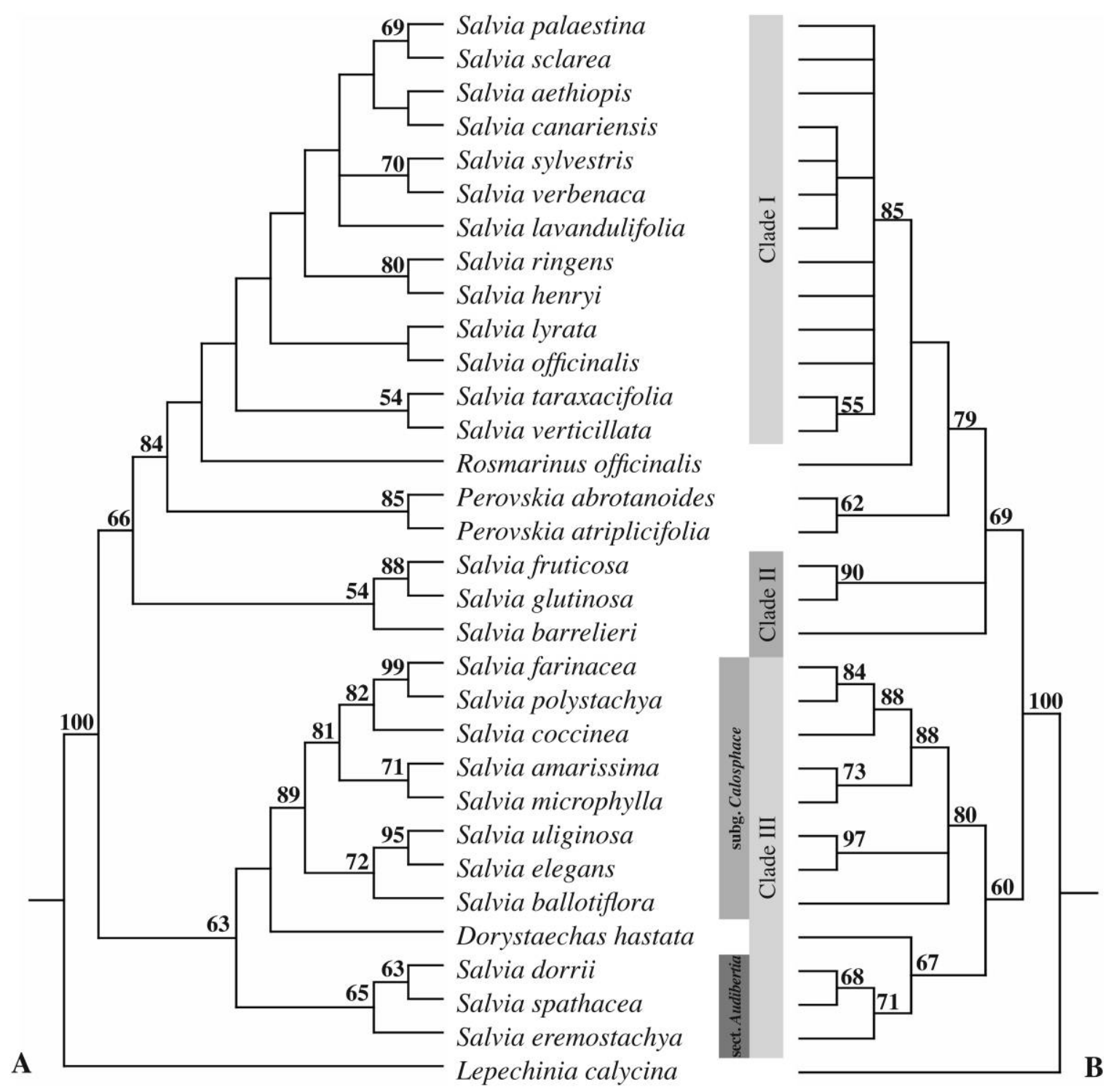

Fig. 7 Strict consensus tree of 32 taxa in Salviinae. Bootstrap values $(>50 \%)$ are indicated above the branches. A, Strict consensus of two most parsimonious trees generated by combined data set. $B$, Strict consensus of 474 most parsimonious trees resulting from $r b c L$ data only.

All previous pollen studies in Salviinae are based on acetolyzed material, and the size measurements of acetolyzed pollen in this study generally agree with those of previous literature data. We showed that critical-point-dried pollen grains were always considerably smaller $(8 \%-40 \%)$ than grains of the same specimens after acetolysis. Acetolysis is the standard method for pollen observation, but there are still questions about its possible side effects (Erdtman 1960). Specifically, the size effect of acetolysis was discussed by Reitsma (1969). He stated that the pollen grains increase in size during boiling in the acetolysis mixture, but he also mentioned that there were no significant size differences after acetolysis because the size decreased again during the cooling of the mixture in most cases. However, recent studies consistently show an increase of pollen size after acetolysis (Schols et al. 2004b; Lens et al. 2005), as does this study.
It is interesting to note that heterostyly (i.e., the coexistence of genetically controlled hermaphrodite floral types with different style lengths and usually with reciprocal anther positions in pins and thrums; Ganders 1979) is known only for subtribe Salviinae, while in Lamiaceae, gynodioecy (i.e., a mode of sex expression in which separate hermaphroditic and female plants coexist in the same populations; Owens and Ubera-Jiménez 1992) is a particularly common condition. Distyly is reported in Salvia brandegeei (Neisess 1984; Barrett et al. 2000), and it is also known for Perovskia atriplicifolia without any detailed studies (Bokhari and Hedge 1971). We reported P. abrotanoides to be distylous and examined pollen dimorphism (fig. 2G, $2 H$ ). The pollen size differences between the two morphs were highly significant $(E: p<0.0001, P$ : $p<0.001$ ); the thrum type has much larger grains than the pin type (table 2). In general, pollen grains from thrum morphs are 
larger than those from pin morphs (Dulberger 1992). Pollen size is positively correlated with style length in a wide variety of angiosperms (Lee 1978; Plitmann and Levin 1983), which is consistent with the hypothesis that there is a positive correlation between pollen size and length of the pollen tube necessary to achieve fertilization.

Hexacolpate pollen, together with octocolpate pollen, is known to be a synapomorphy for Nepetoideae (Cantino 1992). Octocolpate pollen grain has been reported in $\mathrm{S}$. coccinea by Trudel and Morton (1992), but we found only hexacolpate pollen grains in this species. Tetra- and pentacolpate pollen grains have been observed in some taxa of subfamilies Viticoideae and Lamioideae but never in Nepetoideae (Cantino 1992; AbuAsab and Cantino 1994). However, our results show that seven species from two genera, Dorystaechas and Salvia, have tetra- to octocolpate grains (but not heptacolpate). Hexacolpate pollen grains, however, are always dominant in all taxa studied.

Sexine ornamentation in Salviinae can be divided into perforate and bireticulate types (figs. 3,4 ) and offers systematically informative characters (figs. 6, 8). The genera Lepechinia and Chaunostoma possess perforate pollen (type I; fig. 2A-2F). These genera are sister to all the other genera in Salviinae on the basis of stamen features and molecular data (Epling 1948; Walker et al. 2004; Walker and Sytsma 2007). The close relationship between the two genera and their basal position in the subtribe are corroborated by the shared presence of perforated sexine (fig. 6).

Pollen grains of the genus Perovskia have a simple semitectate sexine ornamentation in the bireticulate group of Salviinae (type II; fig. 2G-2L), while Dorystaechas, Meriandra, Rosmarinus, and four Salvia species possess a bireticulate sexine with thick primary muri (subtype IIIa). The most recent molecular phylogeny of Walker and Sytsma (2007) suggests that Perovskia and Rosmarinus are closely related and in a sister relationship with a clade containing Meriandra and Dorystaechas. Our palynological results show that the genera Meriandra, Dorystaechas, and Rosmarinus share type III, while Perouskia is clearly distinct in having type II sexine ornamentation.

The largest genus, Salvia, shows a considerable variation in aperture numbers and sexine ornamentation types (subtypes IIIa-IIId; figs. 1, 3, 4). Henderson et al. (1968) distinguished nine pollen types on the basis of sexine ornamentation in the genera Salvia, Meriandra, Dorystaechas, and Perovskia, but because they used only LM observations, they were not able to define the fine structure of bireticulate patterns (Emboden 1964; Henderson et al. 1968). Furthermore, our results show the occurrence of a heteromorphic sculpturing pattern in $S$. spathacea (fig. $3 \mathrm{~K}, 3 \mathrm{~L}$ ). This pattern was previously reported only in S. apiana (Henderson et al. 1968), a species closely related to S. spathacea. Afzal-Rafii (1983) showed some evidence in relation to differences in sexine ornamentation types and polyploidy level within the same species. Probably, the occurrence of different sexine ornamentation types within the same pollen grain could also be related to the chromosome number (Afzal-Rafii 1983).

In Salvia, we defined four different sexine ornamentation types (IIIa-IIId), but most taxa studied have subtype IIIb. Sexine ornamentation subtypes IIIc and IIId can be considered derived features because of the more reduced tectum (Walker and Doyle 1975). It is interesting that these sexine ornamenta- tion subtypes occur only in Old World Salvia taxa. However, we cannot detect any link between variation in sexine ornamentation and the proposed infrageneric delimitation of Salvia (Briquet 1897; Epling 1938, 1939; Hedge 1974).

Simple unbranched columellae are a plesiomorphic character and are found in most gynobasic-styled Lamiaceae (AbuAsab and Cantino 1992, 1994). All Salviinae species studied have simple, unbranched columellae and a continuous granular endexine (fig. $5 A-5 H$ ), which is a common feature in the subfamily Nepetoideae (Nabli 1976; Harley 1992; Harley et al. 1992; Moon and Hong 2003).

\section{Phylogenetics of Salviinae}

Although the genus Salvia has been considered to be a morphologically well-supported group, mainly on the basis of its highly derived stamen structure, recent molecular data propose a possible polyphyletic origin of this large genus (Walker et al. 2004; Walker and Sytsma 2007). According to the strict consensus tree resulting from our combined analysis of both palynological data and $r b c L$ sequence data (fig. 7), Salvia is divided into two major groups that correspond to distribution patterns. Although this is a preliminary hypothesis with only 32 taxa, Salvia clade I and II include all members of Bentham's (1876) subgenera Sclarea, Leonia, and Salvia, all distributed in the Old World. Salvia clade III is restricted exclusively to the New World and is composed of the subgenus Calosphace and the section Audibertia (Epling 1938, 1939).

The strict consensus tree of the combined parsimony analysis (fig. $7 A$ ) suggested more or less the same topology as the $r b c L$ sequence data analysis (fig. $7 B$ ). However, our results demonstrate that adding palynological characters to the data matrix resulted in higher BS values for clade III and a better resolution at the terminal nodes. Salvia clade I, for instance, was considerably better resolved in the combined analysis, compared to the polytomy resulting from the $r b c L$ data only (fig. 7).

To evaluate the systematic importance of our palynological characters in Salviinae, selected characters were plotted on one of the most parsimonious trees from $r b c L$ data using MacClade 4 (fig. 8). The genus Lepechinia was supported as sister to the rest of the genera in Salviinae by the number of layers in the sexine ornamentation (char. 8). Characters 9-11, which are related to sexine ornamentation types, have some interesting points for systematic understanding. For instance, thin primary muri (char. 9) and secondary reticulum, including large lumina (char. 11), are restricted to clade I. In addition, these characters could be more derived features based on reduced tectum surface from the palynological point of view (fig. 6; Walker and Doyle 1975). However, any conclusions regarding evolutionary trends in pollen characters in Salviinae need to be carefully considered preliminary, owing to our limited sampling of the ca. 1000 species in the genus.

The distylous species Perouskia abrotanoides shows pollen dimorphism with highly significant size differences correlating with style length. Hexacolpate pollen grains are always dominant in all studied taxa, although some taxa produce pollen with different aperture numbers. Salviinae is a stenopalynous group with hexacolpate pollen, perforate/bireticulate sexine ornamentation, and similar pollen wall stratification. The phylogeny resulting from analyses of both pollen data only and 

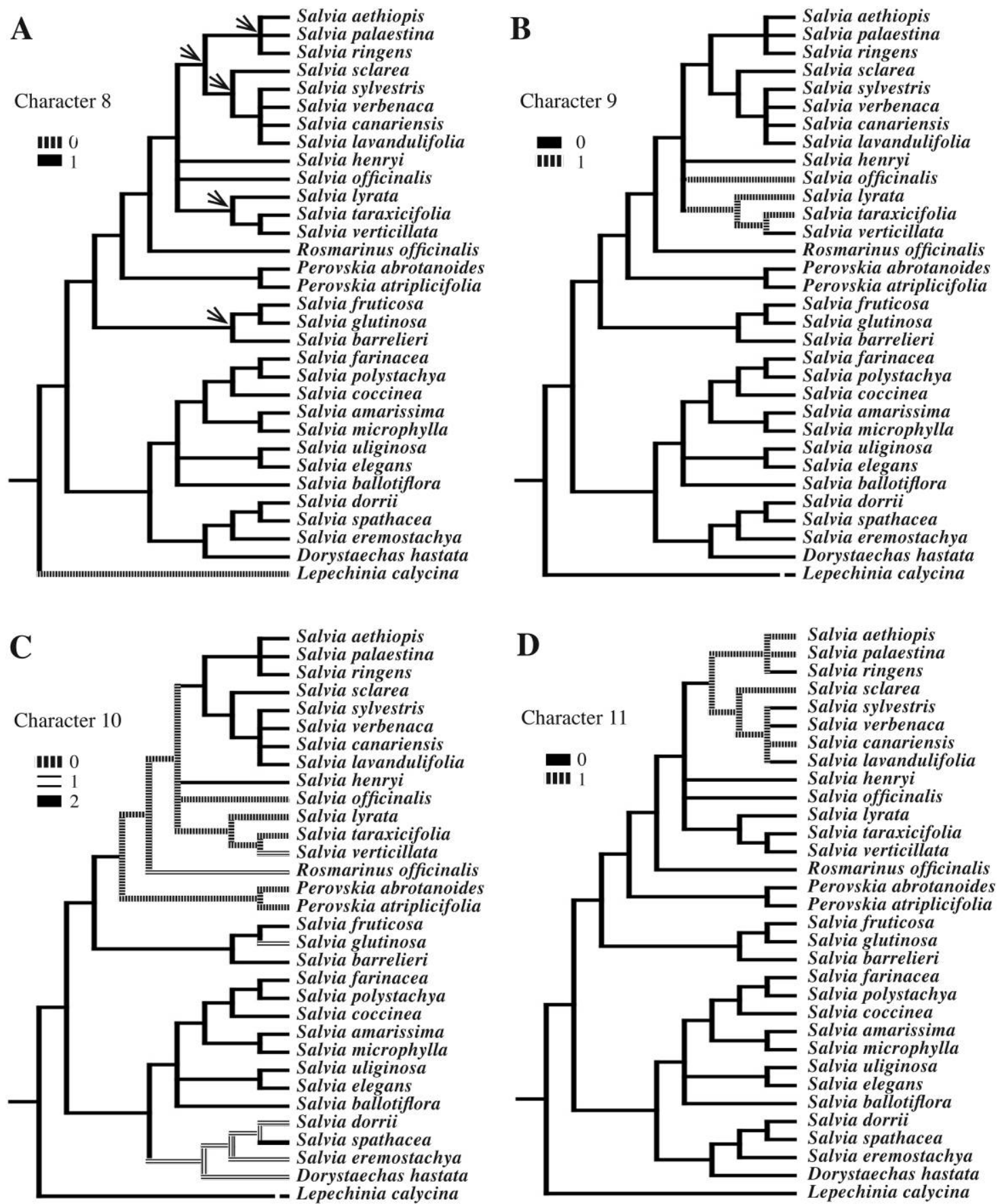

Fig. 8 Palynological characters mapped onto one randomly selected tree of 474 most parsimonious trees from the $r b c L$ data analysis. Clades not present in the strict consensus tree are marked with an arrow on tree $A$. Character states that were not applicable are indicated by a disconnected line in the terminal node of each taxon $(B, C)$. Appendixes $\mathrm{B}$ and $\mathrm{C}$ provide morphological character states and data matrix.

combined molecular and palynological data sets suggests that sexine ornamentation of pollen in Salviinae may have systematic importance, particularly pollen characters (chars. 8-11), which appear correlated with single lineages. Our phylogenetic analyses resulted in an improved resolution of the terminal nodes and increased BS values. However, the lack of resolution based on pollen characters alone and the variability we find in some pollen characters between closely related species suggest that some pollen characters may be under more ecological constraint than phylogenetic constraint. Further pollen studies of Salviinae with expanded taxa will be necessary to investigate potential correlations with ecological factors such as pollinator and habitat. 


\section{Acknowledgments}

We thank the directors of the following herbaria for permitting the examination of specimens, either through loans or during visits: $\mathrm{BR}, \mathrm{GH}$, and $\mathrm{MO}$. Sincere thanks are also due to one anonymous reviewer for the critical reading of the manuscript and helpful suggestions. We are also grateful to Anja Vandeperre (Katholieke Universiteit Leuven) and An Vandoren (TEM, Katholieke Universiteit Leuven) for techni- cal assistance. H.-K. Moon thanks Professor Dr. Suk-Pyo Hong (Kyung Hee University, Seoul) for continuous help and encouragement. A personal research grant from the Katholieke Universiteit Leuven (DB/05/055) was awarded to H.-K. Moon. The Fund for Scientific Research-Flanders (FWO, G.0268.04 and G.0250.05) and the Katholieke Universiteit Leuven (OT/05/35) financially supported this research. S. Vinckier was a postdoctoral fellow of FWO in the course of this study.

\section{Appendix A}

\section{Table A1}

Voucher Specimens of the Subtribe Salviinae That Are Examined in This Study

\begin{tabular}{|c|c|c|}
\hline Species & Subgenus: section & Voucher specimens \\
\hline Chaunostoma mecistandrum Donn. Sm. & & Mexico, Nov. 6, 1939: Matuda $3915(\mathrm{GH})^{\mathrm{a}}$ \\
\hline Dorystaechas hastata Boiss. \& Heldr. ex Benth. & & Turkey, Nov. 5, 1998: Verlooue $3102(\mathrm{BR})^{\mathrm{ab}}$ \\
\hline Lepechinia calycina (Benth.) Epling ex Munz. & & U.S.A., California, June 16, 1953: Sharsmith $4229(\mathrm{BR})^{\mathrm{ab}}$ \\
\hline Lepechinia caulescens (Orteg.) Epling & & Mexico, Flor de Maria, Sept. 4, 1890: Pringle 3264 (BR) \\
\hline Meriandra bengalensis (Roxb.) Benth. & & $\begin{array}{l}\text { Yemen Arab Republic, Sept. 12, 1977: Lavranos \& Newton } \\
15796(\mathrm{MO})^{\mathrm{a}}\end{array}$ \\
\hline Perovskia abrotanoides Kar. (pin type) & & $\begin{array}{l}\text { India, Himalaya Mtns., July 11, 1976: Billiet \& Leonard } \\
6888 \text { (BR) }\end{array}$ \\
\hline P. abrotanoides Kar. (thrum type) & & $\begin{array}{l}\text { India, Himalaya Mtns., July 4, 1976: Billiet \& Leonard } \\
6805(\mathrm{BR})^{\mathrm{a}}\end{array}$ \\
\hline Perovskia atriplicifolia Benth. & & Pakistan, Oct. 17, 1975: Dar \& Hassan 60 (GH) \\
\hline Rosmarinus officinalis $\mathrm{L}$. & & Spain, Mallorca, Sept. 18, 1983: Cnops $83.56(\mathrm{BR})^{\mathrm{ab}}$ \\
\hline Salvia aethiopis $\mathrm{L}$. & Sclarea: Aethiopis & France, July 1979: Sotiaux s.n. (BR) $)^{\mathrm{ab}}$ \\
\hline S. amarissima Ort. & Calosphace: Uricae & $\begin{array}{l}\text { Guatemala, July 1906: Turckheim } 6040 \text { (BR); Mexico, } \\
\text { Hidalgo, July 18, 1989: Pringle s.n. (BR) }\end{array}$ \\
\hline S. ballotiflora Benth. & Calosphace: Tomentellae & $\begin{array}{l}\text { U.S.A., Comanche Spring, TX, 1849-1851: Lindheimer } \\
1087 \text { (BR) }\end{array}$ \\
\hline S. barrelieri Etl. & Salvia: Plethiosphace & $\begin{array}{l}\text { Morocco, Atlas Mtns., July 2, 1988: Lewalle } 12101 \text { (BR) } \\
\text { Morocco, May 1, 1936: Garnett s.n. (BR); Morocco, } \\
\text { May 13, 1990: Lewalle } 13022 \text { (BR); Spain, Embalso de } \\
\text { Barbate, May 10, 1901: Evrard 12694 (BR) }\end{array}$ \\
\hline S. canariensis $\mathrm{L}$. & Schraderia: Nactosphace & $\begin{array}{l}\text { Spain, Canary Islands, Gran Canaria, Mar. 22, 1969: } \\
\text { Kunkel } 12676 \text { (BR) }\end{array}$ \\
\hline S. coccinea Juss. ex Murr. & Calosphace: Subrotundae & $\begin{array}{l}\text { Portugal, Madeira, Apr. 4, 1900: Bornmüller } 1074 \text { (BR); } \\
\text { U.S.A., Oswego, NY, without date: Wibbe } 1879 \text { (BR) }\end{array}$ \\
\hline S. dorrii (Kell.) Abrams & NI: Audibertia & $\begin{array}{l}\text { U.S.A., Glen Canyon City, UT, May 23, 1965: Cronquist } \\
10171 \text { (BR) }\end{array}$ \\
\hline S. elegans Vahl & Calosphace: Incarnatae & Mexico, Michoacan, Nov. 1891: Pringle 22 (BR) \\
\hline S. eremostachya Jeps. & NI: Audibertia & $\begin{array}{l}\text { U.S.A., Riverside County, CA, May 18, 1958: Raven } \\
13000 \text { (BR) }\end{array}$ \\
\hline S. farinacea Benth. & Calosphace: Farinaceae & Without locality, without date: Larnoliee I 52 (BR) \\
\hline S. fruticosa Miller & Salvia: Salvia & Cyprus, Larnaca, May 21, 1996: Bouharmont 26496 (BR) \\
\hline S. glutinosa L. & Salvia: Drymosphace & $\begin{array}{l}\text { Without locality, 1912: Sennen } 1799 \text { (LV); without locality, } \\
\text { Aug. 19, 1961: Cnops } 61.36 \text { (BR) }\end{array}$ \\
\hline S. henryi Gray & Leonia: Heterosphace & U.S.A., Arizona, May 25, 1884: Pringle s.n. (BR) \\
\hline S. hispanica $\mathrm{L}$. & Calosphace: Potiles & $\begin{array}{l}\text { Mexico, Bonilla, Oct. 23, 1991: Escobedo } 2236(\mathrm{BR}) \text {; } \\
\text { without locality, without date: Lov } 1540(\mathrm{BR})^{\mathrm{b}}\end{array}$ \\
\hline S. lavandulifolia Vahl & Salvia: Salvia & $\begin{array}{l}\text { Spain, València Province, July 17, 1988: Güemes } \\
14411 \text { (BR) }\end{array}$ \\
\hline S. leucantha Cav. & Calosphace: Albolanatae & Without locality, without date: Lov 1541 (BR) \\
\hline S. lyrata $\mathrm{L}$. & Leonia: Heterosphace & $\begin{array}{l}\text { U.S.A., Norfolk, VA, May 3, 1984: Bray s.n. (BR) }{ }^{\text {b }} \text {, } \\
\text { U.S.A., Brazos County, TX, Apr. 7, 1974: Fryxell } 2364 \\
\text { (BR); without locality, May 25, 1979: Basseles s.n. (BR) }\end{array}$ \\
\hline S. microphylla Kunth. & Calosphace: Fulgentes & $\begin{array}{l}\text { Uruguay, Estancia Rincón, Nov. 24, 1946: Gallinal } \\
5772(\mathrm{BR})\end{array}$ \\
\hline
\end{tabular}




\section{Table A1}

(Continued)

\begin{tabular}{|c|c|c|}
\hline Species & Subgenus: section & Voucher specimens \\
\hline S. officinalis $\mathrm{L}$. & Salvia: Salvia & $\begin{array}{l}\text { Spain, Castille, Miranda de Ebro friches, 1915: Elías } \\
2450(\mathrm{LV})^{\mathrm{a}} \text {; without locality, Cnops } 77.8 \text { (BR) }\end{array}$ \\
\hline S. palaestina Benth. & Salvia: Stenarrhena & Palestine, Apr. 6, 1983: Liston \& Danin 7-8-49/1 (BR) \\
\hline S. polystachya Ort. & Calosphace: Polystachyae & Mexico, Hidalgo, Oct. 3, 1980: Rodriguez 5019 (BR) \\
\hline S. reflexa Hornem. & Calosphace: Glareosae & $\begin{array}{l}\text { France, Gironde, Bordeaux, Sept. 11, 1939: Bouchon } \\
\text { s.n. (BR) }\end{array}$ \\
\hline S. ringens $\mathrm{Sm}$. & Salvia: Salvia & $\begin{array}{l}\text { Greece, Kalavryta, Achaea, May 29, 1983: Bouharmont } \\
16085(\mathrm{BR})^{\mathrm{a}}\end{array}$ \\
\hline S. rypara Briq. & Calosphace: Malacophyllae & Bolivia, Narvaez, Nov. 7, 1993: Billiet \& Jadin 6123 (BR) \\
\hline S. sclarea L. & Salvia: Stenarrhena & France, July 24, 1953: Andre 11 (BR) \\
\hline S. spathacea Greene & NI: Audibertia & U.S.A., California, June 3, 1993: Evrard 11.835 (BR $)^{\mathrm{ab}}$ \\
\hline S. splendens Sello ex Roem. et Schult. & Calosphace: Secundae & Brazil, Brasilia, 1920: Wibbe s.n. (BR) \\
\hline S. sylvestris $\mathrm{L}$. & Salvia: Plethiosphaceae & Hungary, Pelomee, July 1971: Vanden s.n. (BR) \\
\hline S. taraxacifolia Hook. fil. & Salvia: Salvia & Morocco, July 9, 1984: Lewalle 11087 (BR) \\
\hline S. uliginosa Benth. & Calosphace: Uliginosae & $\begin{array}{l}\text { Argentina, Punta Lara, Buenos Aires, Mar. 15, 1955: } \\
\text { Pedersen } 3321 \text { (BR) }\end{array}$ \\
\hline S. verbenaca $\mathrm{L}$. & Salvia: Plethiosphaceae & $\begin{array}{l}\text { Without locality, 1973: Witte } 17281(\mathrm{LV})^{\mathrm{a}} \text {; without locality, } \\
\text { 1919: Sennen s.n. (LV); without locality, 1877: Alke } \\
22 \text { (BR) }\end{array}$ \\
\hline S. verticillata $\mathrm{L}$. & Covola: Hemisphace & $\begin{array}{l}\text { Poland, Karpates, Orientales, July 20, 1982: Lisowski } \\
83719 \text { (BR); France, Seine River, July 3, 1901: } \\
\text { Anonymous s.n. (LV) }\end{array}$ \\
\hline
\end{tabular}

Note. Sections after Briquet (1897), Epling (1938, 1939), and Hedge (1974). NI = not indicated.

a Orbicule presence checked.

b Transmission electron microscopic observation.

\section{Appendix B}

\section{Pollen Morphological Character States Used in the Cladistic Analysis Combined with rbcL Sequence Data from GenBank of Salvia and Related Taxa}

1. Length of polar axis of pollen $(P)$.

2. Equatorial diameter of pollen $(E)$.

3. Pollen colpus length.

4. Exine thickness at the pole.

5. Exine thickness at the equator.

6. Pollen shape classes $(P / E)$.

7. Number of pollen apertures: six (0); including heteromorphic aperture number (tetra- to octocolpate pollen, except heptacolpate pollen (1).

8. Pollen sculpturing: one layer (0); two layer (1).

9. Primary muri thickness: thicker than secondary muri (0); more or less same thickness as secondary muri (1).

10. Number of secondary lumina: $<5(0) ; 5-10(1) ;>10(2)$.

11. Secondary reticulum with large lumina in the middle: absent $(0)$; present (1).

12. Structure of columellate stratum of exine: simple $(0)$; branched (1).

13. Orbicules: absent (0); present (1).

The continuous character states 1-6 were coded using Thiele's gap weighting method, as implemented by MorphoCode (see also table 2; Thiele 1993; Schols et al. 2004a). Characters 12 and 13 are constant and are excluded from the data matrix in appendix C. 


\section{Appendix C}

Table C1

Data Matrix of Morphological Characters of Salvia and Related Taxa with GenBank Accession Number of rbcL Sequences Data

\begin{tabular}{|c|c|c|c|c|c|c|c|c|c|c|c|c|}
\hline \multirow[b]{2}{*}{ Taxon } & \multicolumn{11}{|c|}{ Morphological character nos. } & \multirow[b]{2}{*}{ GenBank accession no. } \\
\hline & 1 & 2 & 3 & 4 & 5 & 6 & 7 & 8 & 9 & 10 & 11 & \\
\hline Chaunostoma mecistandrum Donn. Sm. & 8 & 7 & 9 & 7 & 8 & 5 & 0 & 0 & $\ldots$ & $\ldots$ & 0 & $\ldots$ \\
\hline Dorystaechas hastata Boiss. \& Heldr. ex Benth. & 2 & 2 & 3 & 9 & 8 & 3 & 1 & 1 & 0 & 1 & 0 & AY570383 \\
\hline Lepechinia calycina (Benth.) Epling ex Munz. & 5 & 6 & 6 & 7 & 7 & 1 & 0 & 0 & $\ldots$ & $\ldots$ & 0 & AY 570386 \\
\hline Lepechinia caulescens (Orteg.) Epling & 8 & 5 & 8 & 7 & 7 & 7 & 0 & 0 & $\ldots$ & $\ldots$ & 0 & $\ldots$ \\
\hline Meriandra bengalensis (Roxb.) Benth. & 4 & 3 & 4 & 5 & 4 & 4 & 0 & 1 & 0 & 1 & 0 & $\ldots$ \\
\hline Perovskia abrotanoides Kar. & 4 & 5 & 4 & 7 & 7 & 1 & 0 & 1 & 0 & 0 & 0 & Z37428 \\
\hline Perovskia atriplicifolia Benth. & 4 & 4 & 4 & 7 & 7 & 2 & 0 & 1 & 0 & 0 & 0 & AY570391 \\
\hline Rosmarinus officinalis L. & 5 & 5 & 5 & 7 & 6 & 2 & 0 & 1 & 0 & 1 & 0 & Z37434 \\
\hline Salvia aethiopis L. & 5 & 4 & 5 & 8 & 8 & 5 & 0 & 1 & 0 & 2 & 1 & Z37436 \\
\hline S. amarissima Ort. & 2 & 1 & 2 & 5 & 6 & 5 & 0 & 1 & 0 & 2 & 0 & AY570393 \\
\hline S. ballotiflora Benth. & 2 & 0 & 2 & 2 & 3 & 7 & 0 & 1 & 0 & 2 & 0 & AY570396 \\
\hline S. barrelieri Etl. & 8 & 6 & 9 & 7 & 7 & 8 & 1 & 1 & 0 & 2 & 0 & Z37448 \\
\hline S. canariensis L. & 6 & 5 & 6 & 7 & 7 & 5 & 0 & 1 & 0 & 2 & 1 & Z37439 \\
\hline S. coccinea Juss. ex Murr. & 7 & 7 & 5 & 5 & 6 & 3 & 0 & 1 & 0 & 2 & 0 & AY570407 \\
\hline$S$ dorrii (Kell.) Abrams & 7 & 6 & 7 & 4 & 5 & 5 & 0 & 1 & 0 & 1 & 0 & AY570413 \\
\hline S. elegans Vahl & 4 & 3 & 5 & 3 & 4 & 6 & 0 & 1 & 0 & 2 & 0 & Z37449 \\
\hline S. eremostachya Jeps. & 9 & 9 & 9 & 5 & 6 & 3 & 1 & 1 & 0 & 2 & 0 & AY 570414 \\
\hline S. farinacea Benth. & 1 & 1 & 2 & 3 & 3 & 3 & 0 & 1 & 0 & 2 & 0 & AY 570415 \\
\hline S. fruticosa Miller & 7 & 5 & 7 & 7 & 7 & 7 & 0 & 1 & 0 & 2 & 0 & AY 570416 \\
\hline S. glutinosa L. & 7 & 6 & 8 & 9 & 9 & 5 & 0 & 1 & 0 & 1 & 0 & Z37440 \\
\hline S. henryi Gray & 8 & 7 & 9 & 7 & 7 & 5 & 0 & 1 & 0 & 2 & 0 & AY 570420 \\
\hline S. hispanica L. & 2 & 1 & 2 & 1 & 2 & 3 & 0 & 1 & 0 & 1 & 0 & $\ldots$ \\
\hline S. lavandulifolia Vahl & 6 & 5 & 6 & 7 & 6 & 4 & 0 & 1 & 0 & 2 & 0 & Z37444 \\
\hline S. leucantha Cav. & 1 & 1 & 0 & 2 & 2 & 3 & 1 & 1 & 0 & 2 & 0 & $\ldots$ \\
\hline S. lyrata L. & 7 & 7 & 6 & 6 & 6 & 3 & 0 & 1 & 1 & 0 & 0 & AY 570426 \\
\hline S. microphylla Kunth. & 3 & 2 & 4 & 4 & 4 & 5 & 0 & 1 & 0 & 2 & 0 & AY570427 \\
\hline S. officinalis L. & 7 & 5 & 7 & 6 & 7 & 5 & 0 & 1 & 1 & 0 & 0 & AY 570431 \\
\hline S. palaestina Benth. & 7 & 5 & 7 & 4 & 5 & 7 & 1 & 1 & 0 & 2 & 1 & AY 570433 \\
\hline S. polystachya Ort. & 0 & 0 & 1 & 0 & 0 & 2 & 0 & 1 & 0 & 2 & 0 & AY 570435 \\
\hline S. reflexa Hornem. & 1 & 1 & 2 & 2 & 1 & 2 & 0 & 1 & 0 & 2 & 0 & $\ldots$ \\
\hline S. ringens $\mathrm{Sm}$. & 8 & 5 & 9 & 8 & 9 & 9 & 0 & 1 & 0 & 2 & 0 & AY 570437 \\
\hline S. rypara Briq. & 0 & 0 & 1 & 1 & 1 & 3 & 0 & 1 & 0 & 2 & 0 & $\ldots$ \\
\hline S. sclarea L. & 7 & 7 & 8 & 6 & 5 & 3 & 0 & 1 & 0 & 2 & 1 & AY570439 \\
\hline S. spathacea Greene & 8 & 8 & 9 & 5 & 6 & 4 & 0 & 1 & 0 & 2 & 0 & AY 570442 \\
\hline S. splendens Sello ex Roem. et Schult. & 8 & 9 & 7 & 7 & 8 & 1 & 1 & 1 & 1 & 2 & 1 & $\ldots$ \\
\hline S. sylvestris L. & 4 & 3 & 4 & 3 & 4 & 3 & 0 & 1 & 0 & 2 & 0 & AY 570446 \\
\hline S. taraxacifolia Hook. fil. & 4 & 6 & 5 & 5 & 5 & 1 & 0 & 1 & 1 & 0 & 0 & AY570445 \\
\hline S. uliginosa Benth. & 1 & 2 & 1 & 1 & 1 & 0 & 1 & 1 & 0 & 2 & 0 & Z37451 \\
\hline S. verbenaca L. & 5 & 3 & 6 & 6 & 6 & 6 & 0 & 1 & 0 & 2 & 0 & AY570423 \\
\hline S. verticillata L. & 2 & 1 & 3 & 4 & 3 & 5 & 0 & 1 & 0 & 1 & 0 & Z37452 \\
\hline
\end{tabular}

\section{Literature Cited}

Abu-Asab MS, PD Cantino 1992 Pollen morphology in subfamily Lamioideae (Labiatae) and its phylogenetic implications. Pages 97-112 in RM Harley, T Reynolds, eds. Advances in Labiatae science. Royal Botanic Gardens, Kew.

1994 Systematic implications of pollen morphology in subfamilies Lamioideae and Pogostemonoideae (Labiatae). Ann Mo Bot Gard 81:653-686.

Afzal-Rafii Z 1983 Les pollens du genre Salvia et leur évolution. Pollen Spores 25:351-366.

Barrett SCH, DH Wilken, WW Cole 2000 Heterostyly in the Lamiaceae: the case of Salvia brandegeei. Plant Syst Evol 223:211-219.
Bentham G 1876 Labiatae. Pages 1160-1196 in G Bentham, JD Hooker, eds. Genera plantarum. Vol 2. Reeve, London.

Bokhari MH, IC Hedge 1971 Observations on the tribe Meriandreae of the Labiatae. Notes R Bot Gard Edinb 31:53-67.

Briquet J 1897 Labiatae. Pages 183-287 in A Engler, K Prantl, eds. Die naturlichen pflanzenfamilien nebst ihrer Gattungen und wichtigeren Arten. Vol IV. Engelmann, Leipzig.

Cantino PD 1992 Evidence for a polyphyletic origin of the Labiatae. Ann Mo Bot Gard 79:361-379.

Claßen-Bockhoff R, M Crone, E Baikova 2004 Stamen development in Salvia L.: homology reinvestigated. Int J Plant Sci 165:475-498. 
Dulberger R 1992 Floral polymorphism and their functional significance in the heterostylous syndrome. Pages 41-84 in SCH Barrett, ed. Evolution and function of heterostyly. Springer, Berlin.

Emboden WA 1964 Pollen morphology of the genus Salvia section Audibertia. Pollen Spores 6:527-536.

Epling C 1938 The California salvias. Ann Mo Bot Gard 25:95-188. 1939 A revision of Salvia, subgenus Calosphace. Repert Spec Nov Regni Veg Beih 110:1-383.

— 1948 A synopsis of the tribe Lepechinieae (Labiatae). Brittonia 6:352-364.

Erdtman G 1945 Pollen morphology and plant taxonomy. IV. Labiatae, Verbenaceae and Avicenniaceae. Sven Bot Tidskr 39:279-285.

1960 The acetolysis method: a revised description. Sven Bot Tidskr 54:561-564.

Felsenstein J 1985 Confidence limits on phylogenies: an approach using the bootstrap. Evolution 39:783-791.

Ganders FR 1979 The biology of heterostyly. N Z J Bot 17:607-635.

Harley MM 1992 The potential value of pollen morphology as an additional taxonomic character in subtribe Ociminae (Ocimeae: Nepetoidaea: Labiatae). Pages 125-138 in RM Harley, T Reynolds, eds. Advances in Labiatae science. Royal Botanic Gardens, Kew.

Harley MM, A Paton, RM Harley, PG Cade 1992 Pollen morphological studies in tribe Ocimeae (Nepetoidaea: Labiatae). I. Ocimum L. Grana 31:161-176.

Harley RM, S Atkins, AL Budantsev, PD Cantino, BJ Conn, R Grayer, MM Harley, et al 2004 Labiatae. Pages 167-275 in JW Kadereit, ed. The families and genera of vascular plants. VII. Flowering plants: Dicotyledons: Lamiales (except Acanthaceae including Avicenniaceae). Springer, Berlin.

Hedge IC 1974 A revision of Salvia in Africa and the Canary Islands. Notes R Bot Gard Edinb 33:1-121.

Henderson DM, H Prentice, IC Hedge 1968 Pollen morphology of Salvia and some related genera. Grana Palynol 8:70-85.

Holmgren PK, NH Holmgren, LC Barnett 1990 Index herbariorum. Vol 1. The herbaria of the world. New York Botanical Garden, New York.

Hruby K 1962 Key to the supraspecific taxa of the genus Salvia. Preslia 34:368-373.

Huysmans S, G El-Ghazaly, E Smets 1998 Orbicules in angiosperms: morphology, function, distribution, and relation with tapetum types. Bot Rev 64:240-272.

2000 Orbicules: still a well-hidden secret of the anther. Pages 201-212 in B Nordenstam, G El-Ghazaly, M Kassas, eds. Plant systematics for the 21st century. Vol 77 . Portland, London.

Lee S 1978 A factor analysis study of the functional significance of angiosperm pollen. Syst Bot 3:1-19.

Lens F, S Dressler, S Vinckier, S Janssens, S Dessein, L Van Evelghem, E Smets 2005 Palynological variation in balsaminoid Ericales. I. Marcgraviaceae. Ann Bot 96:1047-1060.

Maddison WP, DR Maddison 2000 MacClade 4.0: analysis of phylogeny and character evolution. Sinauer, Sunderland, MA.

Maddison WP, DL Swofford, WP Maddison 1997 NEXUS: an extendible file format for systematic information. Syst Biol 46:590-621.

Moon H-K, SP Hong 2003 Pollen morphology of the genus Lycopus (Lamiaceae). Ann Bot Fenn 40:191-198.

Nabli MA 1976 Etude ultrastructurale comparée de l'exine chez quelques genres de Labiatae. Pages 499-525 in IK Ferguson, J Muller, eds. The evolutionary significance of the exine. Academy Press, London.

Neisess KR 1984 Heterostyly in Salvia brandegeei (Lamiaceae). Madroño 31:253-254.
Owens SJ, JL Ubera-Jiménez 1992 Breeding systems in Labiatae. Pages 257-280 in RM Harley, T Reynolds, eds. Advances in Labiatae science. Royal Botanic Gardens, Kew.

Plitmann U, D Levin 1983 Pollen-pistil relationships in the Polemoniaceae. Evolution 66:708-720.

Pobedimova EG 1954 Labiatae. Pages 245-363 in BK Shishkin, ed. Flora of the U.S.S.R. Vol 21. Labiatae. Izdatel'stvo Akademii Nauk SSR, Moscow.

Punt W, S Blackmore, S Nilsson, A Le Thomas 1994 Glossary of pollen and spore terminology. LPP Foundation, Utrecht.

Raj B, G El-Ghazaly 1987 Morphology and taxonomic application of orbicules (Ubisch bodies) in Chloanthaceae. Pollen Spores 29: 151-166.

Reitsma T 1969 Size modifications of recent pollen under treatments. Rev Palaeobot Palynol 9:175-202.

Schols P, S Dessein, C D’Hondt, S Huysmans, E Smets 2002 Carnoy: a new digital measurement tool for palynology. Grana 41:124-126.

Schols P, C D'Hondt, K Geuten, V Merckx, S Janssens, E Smets 2004a MorphoCode: coding quantitative data for phylogenetic analyses. Phyloinformatics 4:1-4.

Schols P, K Es, C D'Hondt, V Merckx, E Smets 2004b A new enzyme-based method for the treatment of fragile pollen grains collected from herbarium material. Taxon 53:777-782.

Stibal EP 1934 A revision of Chinese and east Burmese species of Salvia. Acta Horti Gotob 9:101-165.

1935 Revision der indischen und tibetanischen Arten der Gattung Salvia. Repert Spec Nov Regni Veg 39:173-186.

Suarez-Cervera M, JA Seoane-Camba 1986 Ontogénèse des grains de pollen de Lavandula dentata $\mathrm{L}$. et évolution des cellules tapétales. Pollen Spores 28:5-28.

Swofford DL 2002 PAUP*: phylogenetic analysis using parsimony ("and other methods). Version 4.0b10. Sinauer, Sunderland, MA.

Thiele K 1993 The holy grail of the perfect character: the cladistic treatment of morphometric data. Cladistics 9:275-304.

Thorne RF 1992 Classification and geography of the flowering plants. Bot Rev 58:225-348.

Trudel MC, JK Morton 1992 Pollen morphology and taxonomy in North American Labiatae. Can J Bot 70:975-995.

Varghese TM, DPS Verma 1968 Pollen morphology of some Indian Labiatae. J Palynol 4:77-83.

Vij SP, SK Kashyap 1975 Pollen grain studies in some Labiatae. J Palynol 11:29-42.

Vinckier S, E Smets 2002 Morphology, ultrastructure and typology of orbicules in Loganiaceae s.l. and related genera, in relation to systematics. Rev Palaeobot Palynol 119:161-189.

Wagstaff SJ 1992 A phylogenetic interpretation of pollen morphology in tribe Mentheae (Labiatae). Pages 113-124 in RM Harley, T Reynolds, eds. Advances in Labiatae science. Royal Botanic Gardens, Kew.

Walker JB, KJ Sytsma 2007 Staminal evolution in the genus Salvia (Lamiaceae): molecular phylogenetic evidence for multiple origins of the staminal lever. Ann Bot 100:375-391.

Walker JB, KJ Sytsma, J Treutlein, M Wink 2004 Salvia (Lamiaceae) is not monophyletic: implications for the systematics, radiation, and ecological specializations of Salvia and tribe Mentheae. Am J Bot 91:1115-1125.

Walker JW, JA Doyle 1975 The bases of angiosperm phylogeny: palynology. Ann Mo Bot Gard 62:664-723.

Wunderlich R 1967 Ein Vorschlag zu einer natürlichen Gliederung der Labiaten auf Grund der Pollenkörner, der Samenentwicklung und des reifen Samens. Oesterr Bot Z 114:383-483. 